\title{
PROBLEMATIKA PEMBEBANAN HAK TANGGUNGAN DENGAN OBJEK TANAH YANG BELUM BERSERTIPIKAT
}

\author{
Siti Malikhatun Badriyah \\ Fakultas Hukum Universitas Diponegoro \\ Jalan Prof. Soedarto, SH, Tembalang Semarang \\ Email: malikha_b@yahoo.com
}

\begin{abstract}
In credit agreements developed in the community, mortgage right become an important requirement for ensuring that the achievements in accordance with the agreement. Problematic raised in this research is how the regulation mortgage right with the object of land that has not been certified and how the implementation of mortgage rights with the object of land that has not been certified. This study aims to assess and analyze the setting and implementation of mortgage right with land that have not been certified as an object. From this study it can be concluded that there is a gap in the implementation of the rules regarding the imposition of a security ortgage interest with the object of land rights that have not been certified with implementation in the field.
\end{abstract}

Keywords: Implementation Mortgage Right; Object of Mortgage Right; Land Have Not Been Not Certified.

\begin{abstract}
Abstrak
Dalam perjanjian kredit yang berkembang di masyarakat, Hak Tanggungan menjadi suatu kebutuhan penting untuk menjamin dilaksanakan prestasi sesuai dengan perjanjian.. Problematika yang diangkat dalam penelitian ini adalah bagaimana pengaturan hak tanggungan dengan objek tanah yang belum bersertipikat dan bagaimana pelaksanaan hak tanggungan dengan objek tanah yang belum bersertipikat. Penelitian ini bertujuan untuk mengkaji dan menganalisis pengaturan dan pelaksanaan Hak Tanggungan dengan objek tanah yang belum bersertipikat. Dari penelitian ini dapat disimpulkan bahwa dalam pelaksanaan terdapat kesenjangan antara peraturan mengenai pembebanan hak tanggungan dengan objek hak atas tanah yang belum bersertipikat dengan pelaksanaan di lapangan. Dengan demikian maksud diberikannya kesempatan bagi pemilik hak atas tanah yang belum bersertipikat untuk memperoleh kredit sebagaimana ditentukan oleh UUHT menjadi tidak terwujud.
\end{abstract}

Kata Kunci: Hak Tanggungan; Objek Hak Tanggungan; Tanah Belum Bersertipikat.

\section{A. Pendahuluan}

Dalam hukum hal yang selalu menjadi perhatian pokok adalah adanya kepastian hukum (rechtssicherheit), kemanfaatan (zweckmassigkeit) dan keadilan (gerechtigkeit), yang oleh Gustav Radbruch disebut sebagai ide dasar hukum (rechtsidee). Demikian juga dalam hukum jaminan, ketiga hal tersebut seharusnya diperhatikan. ${ }^{1}$ Dana menjadi kebutuhan yang sangat vital bagi siapapun. Pendanaan dapat berasal dari diri sendiri maupun dari pinjaman pihak lain. Dalam hal dana berasal dari pinjaman pihak lain, pada umumnya pihak yang menyalurkan dana sebagai kreditor memiliki risiko yang tinggi, sehingga menghendaki adanya jaminan. ${ }^{2}$ Untuk menjamin keamana piutang kreditor itulah jaminan menjadi faktor yang sangat krusial. Munir Fuady menyebutkan bahwa jaminan utang adalah pemberian keyakinan kepada keditor atas pembayaran utang-utang yang telah diberikannya kepada

1. Sudikno Mertokusumo, 1996, Penemuan Hukum Sebuah Pengantar, Yogyakarta, Liberty, hlm. 6-7.

2. Siti malikhatun Badriyah, 2005, Jaminan Fidusia di Indonesia (Setelah Berlakunya Undang-Undang No. 42 Tahun 1999), Semarang, Badan Penerbit Universitas Diponegoro, hlm. 3. 
debitor yang timbul karena hukum ataupun karena suatu perjanjian. ${ }^{3}$ Salah satu lembaga jaminan yang sering dipraktikkan saat ini adalah hak tanggungan.

Dalam Pasal 1 angka 1 Undang-Undang Nomor 4 Tahun 1996 tentang Hak Tanggungan, yang selanjutnya disebut UUHT disebutkan bahwa Hak Tanggungan Atas Tanah Beserta Benda-benda yang Berkaitan dengan Tanah yang selanjutnya disebut Hak Tanggungan adalah hak jaminan yang dibebankan pada hak atas tanah sebagaimana dimaksud dalam Undang-Undang Nomor 5 Tahun 1960 tentang Peraturan Dasar Pokokpokok Agraria, berikut atau tidak berikut benda-benda lain yang merupakan satu kesatuan dengan tanah itu, untuk pelunasan utang tertentu yang memberikan kedudukan diutamakan kepada kreditor tertentu terhadap kreditor lain.

Hak milik atas tanah merupakan hak yang turun temurun, terkuat dan terpenuh yang dapat dipunyai orang atas tanah dan m e m beri ke we nangan untuk menggunakannya bagi segala macam keperluan selama waktu yang tidak terbatas, sepanjang tidak ada larangan khusus untuk itu (Pasal 20 UUPA). Bukti kepemilikan Hak Milik atas Tanah tersebut yang kuat dan sah secara administratif adalah berupa sertipikat hak milik atas tanah yang dikeluarkan oleh pejabat yang berwenang dalam hal ini adalah Kantor Pertanahan, namun ada juga hak milik atas tanah yang belum bersertipikat, sehingga belum memiliki bukti kepemilikan karena proses administrasinya belum selesai atau belum dilaksanakan.

UUHT memberikan kesempatan bagi pemilik hak atas tanah yang belum bersertipikat untuk menjaminkan hak atas tanahnya dengan hak tanggungan. Hal ini disebutkan dalam Pasal 10 ayat (2) UUHT yang menyatakan bahwa apabila objek Hak Tanggungan berupa hak atas tanah yang berasal dari konversi hak lama yang telah memenuhi syarat untuk didaftarkan akan tetapi pendaftarannya belum dilakukan, pemberian hak tanggungan dilakukan bersamaan dengan permohonan pandaftaran hak atas tanah yang bersangkutan. Meskipun dalam peraturan perundang-undangan dimungkinkan pembebanan hak tanggungan terhadap tanah yang belum bersertipikat, namun pada umumnya pemilik hak atas tanah yang belum bersertipikat mengalami kesulitan karena pada umumnya kreditor menghendaki tanah yang sudah bersertipikat karena sudah ada bukti kuat adanya kepemilikan hak atas tanah. Hal demikian menjadikan kendala bagi pemilik hak atas tanah yang belum bersertipikat, apabila ingin memperoleh dana dari pihak lain, yaitu kreditor.

Dari uraian di atas maka muncul permasalahan sebagai berikut:

1. Bagaimana pengaturan hak tanggungan dengan objek tanah yang belum bersertipikat?

2. Bagaimana pembebanan hak tanggungan dengan objek tanah yang belum bersertipikat?

\section{B. Pembahasan}

1. Pengaturan Hak Tanggungan dengan Objek Hak Atas Tanah yang Belum Bersertipikat

Eksistensi hukum di dalam masyarakat pada dasarnya berfungsi untuk melindungi kepentingan manusia. ${ }^{4}$ Pengaturan di dalam perundang-undangan menjadi suatu upaya lebih memberikan kepastian hukum dalam rangka perlindungan hukum yang seimbang bagi para pihak dalam suatu hubungan hukum. Hal ini sejalan dengan konsep asas hukum ekonomi yang mengandung nilai-nilai untuk melindungi berbagai aspek kehidupan kemanusiaan dalam kegiatan ekonomi dalam pengertian luas sebagaimana dikemukakan oleh Sri Redjeki Hartono, ${ }^{5}$ yang mencakup asas keseimbangan kepentingan, asas pengawasan publik, serta asas campur tangan negara terhadap kegiatan ekonomi. Diaturnya Hak Tanggungan ini tentu dimaksudkan untuk memberikan perlindungan hukum dan kepastian hukum baik bagi pihak kreditor Pemegang Hak Tanggungan maupun debitor serta pemberi Hak Tanggungan. Arti pentingnya lembaga jaminan termasuk Hak tanggungan ini adalah untuk menjamin pelunasan utang tertentu. Dengan demikian,

3. Munir Fuady, 2013, Hukum Jaminan Utang, Jakarta, Erlangga, hlm. 8.
4. Sudikno Mertokusumo, 2012, Teori Hukum (Edisi Revisi), Yogyakarta, Cahaya Atma Pustaka, hlm. 7
5. Sri Redjeki Hartono, 2007, Hukum Ekonomi Indonesia, Malang, Bayumedia Publishing, hlm. 62-63. 
kreditor akan mempunyai keyakinan bahwa debitor akan melaksanakan prestasi sesuai dengan perjanjian yang telah dibuat oleh para pihak.

Berkaitan dengan hal ini sejalan dengan pendapat Hasanudin Rahman ${ }^{6}$ yang mengemukakan bahwa jaminan adalah tanggungan yang diberikan oleh debitor atau pihak ketiga kepada pihak kreditor, karena pihak kreditor mempunyai suatu kepentingan bahwa debitor harus memenuhi kewajibannya dalam suatu perikatan. Sehubungan dengan hal ini, Kashadi ${ }^{7}$ menyebutkan bahwa Jaminan adalah sesuatu yang diberikan kepada kreditor untuk menimbulkan keyakinan bahwa debitor akan memenuhi kewajiban yang dapat dinilai dengan uang yang timbul dari suatu perikatan.

Karena pentingnya jaminan dalam menunjang perkembangan perekonomian pada khususnya, maka sangat diperlukan pengaturan yang jelas agar ada kepastian dan perlindungan hukum secara berimbang. Demikian juga dalam hal pemberian jaminan dengan objek hak atas tanah sudah diatur secara tegas dalam UUHT.

Dalam Pasal 1 angka 1 UUHT disebutkan bahwa Hak Tanggungan Atas Tanah Beserta Benda-benda yang Berkaitan dengan Tanah yang selanjutnya disebut Hak Tanggungan adalah hak jaminan yang dibebankan pada hak atas tanah sebagaimana dimaksud dalam Undang-undang Nomor 5 Tahun 1960 tentang Peraturan Dasar Pokokpokok Agraria, berikut atau tidak berikut benda-benda lain yang merupakan satu kesatuan dengan tanah itu, untuk pelunasan utang tertentu yang memerikan kedudukan diutamakan kepada kreditor tertentu terhadap kreditor lain.

Dari ketentuan tersebut terlihat bahwa Objek Hak Tanggungan adalah hak atas tanah sebagaimana dimaksud dalam Undangundang Nomor 5 Tahun 1960 tentang Peraturan Dasar Pokok-pokok Agraria, berikut atau tidak berikut benda-benda lain yang merupakan satu kesatuan dengan tanah itu. Dari kata "berikut atau tidak berikut" terlihat bahwa dalam hal ini dianut asas pemisahan horizontal. Hal ini sesuai dengan Hukum Agraria di Indonesia yang menganut prinsip hukum adat yang dalam hal ini menganut asas pemisahan horizontal, yang berarti bahwa perbuatan hukum terhadap tanah tidak secara otomatis mencakup juga perbuatan hukum terhadap benda-benda lain yang ada di atas tanah yang menjadi satu kesatuan dengan dengan tanah. Dalam hal dilakukan perbuatan hukum terhadap tanah berikut benda-benda lain yang ada di atas tanah yang merupakan satu kesatuan dengan tanah harus diperjanjikan secara tegas. Hal ini juga berlaku dalam hal hak atas tanah dijadikan objek Hak Tanggungan, maka jika hak atas tanah dijaminkan berikut bendabenda lain yang menjadi satu kesatuan dengan tanah harus diperjanjikan secara tegas dalam APHT. Hal ini sejalan dengan pemikiran J. Satrio $^{8}$ dengan yang mengemukakan bahwa UUHT tidak menganut asas asesi tetapi menganut prinsip pemisahan horizontal.

Adapun benda-benda yang dapat menjadi objek hak tanggungan adalah:

a. Yang disebutkan dalam Pasal 4 UUHT:

1) Hak Milik, Hak Guna Bangunan dan Hak Guna Usaha yang diatur dalam Pasal 4 ayat (1) UUPA.

2) Hak Pakai atas tanah Negara yang menurut ketentuan yang berlaku wajib didaftarkan dan menurut sifatnya dapat dipindahtangankan.

b. Yang disebut dalam Pasal 27:

1) Rumah susun yang berdiri di atas tanah Hak Milik, Hak Guna Bangunan dan Hak Pakai yang diberikan oleh Negara.

2) Hak Milik atas satuan Rumah Susun, yang bangunannya berdiri di atas tanah Hak Milik, Hak Guna Bangunan dan Hak Pakai yang dberikan oleh Negara.

Hak Milik atas tanah merupakan hak yang turun temurun, terkuat dan terpenuh yang dapat dipunyai orang atas tanah dan m e mberi ke we nangan untuk menggunakannya bagi segala macam keperluan selama waktu yang tidak terbatas, sepanjang tidak ada larangan khusus untuk itu

6 Hasanudin Rahman, 1996, Aspek-aspek Hukum Perikatan Kredit Perbankan, Bandung, Citra Aditya Bakti, hlm. 233,.

7. Kashadi, 2000, Hak Tanggungan dan Jaminan Fidusia, Semarang, Universitas Diponegoro Semarang, hlm. 1.

8. J. Satrio, 2002, Hukum Jaminan, Hak Jaminan Kebendaan, Hak Tanggungan, Buku 2, Cetakan Kesatu, Bandung, PT Citra Aditya Bakti, hlm. 27. 
(Pasal 20 UUPA). Bukti Kepemilikan Hak Milik atas tanah tersebut yang kuat dan sah secara administratif adalah berupa sertipikat hak milik atas tanah yang dikeluarkan oleh pejabat yang berwenang dalam hal ini adalah kantor pertanahan, namun ada juga hak milik atas tanah yang belum bersertipikat sehingga belum mempunyai bukti kepemilikan karena proses administrasinya belum selesai atau belum dilaksanakan. Dalam pasal 10 UUHT dimungkinkan adanya pembebanan Hak Tanggungan terhadap tanah yang belum bersertipikat ini, namun demikian pada waktu pembebanan hak Tanggungan harus sekaligus dilakukan pendaftaran hak atas tanah tersebut. Pasal 10 ayat (3) UUHT menyebutkan bahwa

"Apabila objek Hak Tanggungan berupa hak atas tanah yang berasal dari konversi hak lama yang telah memenuhi syarat untuk didaftarkan akan tetapi pendaftarannya belum dilakukan, pemberian Hak Tanggungan dilakukan bersamaan dengan permohonan pendaftaran hak atas tanah yang bersangkutan."

Ketentuan Pasal 10 ayat (3) UUHT merupakan pengecualian atas prinsip bahwa objek Hak Tanggungan adalah tanah menurut UUPA terdaftar dan dapat dipindahtangankan karena di dalam ketentuan tersebut dimungkinkan adanya Hak Tanggungan atas tanah yang berasal dari konversi hak lama, yang sudah memenuhi syarat untuk pendaftaran, tetapi belum didaftarkan, sehingga belum dapat dikatakan sebagai hak atas tanah menurut UUPA. Karena hak atas tanah bekas hak barat, sejak tanggal 24 September 1980 sudah tidak ada lagi (Keppres No. 32 Tahun 1979 jo. PMDN No. 3 Tahun 1979), maka yang dimaksud dengan "tanah yang berasal dari konversi hak lama" dalam Pasal 10 Ayat (3) UUHT adalah tanahtanah hak adat.

Penjelasan Pasal 10 ayat (3) UUHT menyatakan bahwa kemungkinan untuk pemberian hak tanggungan pada hak atas tanah milik adat dimaksudkan untuk:
a. Memberi kesempatan kepada pemegang
hak atas tanah yang belum bersertifikat untuk memperoleh kredit.
b. Mendorong pensertifikatan hak atas

tanah pada umumnya.

Pengecualian dalam Pasal 10 ayat (3) UUHT diberikan untuk menampung kebutuhan praktik, berupa kemudahan bagi para golongan ekonomi lemah yang membutuhkan kredit dan satu-satunya jaminan yang dimilikinya adalah sebidang persil hak adat yang sebenarnya sudah memenuhi syarat untuk dikonversi sebagai hak atas tanah menurut UUPA. Tanah seperti ini pada umumnya bukti kepemilikannya berupa girik, petuk, letter $\mathrm{C}$ dan lain-lain bukti, yang sebenarnya tidak dapat dikatakan sebagai bukti kepemilikan tetapi hanya sekedar merupakan ketetapan pemerintah mengenai siapa yang wajib membayar pajak atas persil yang berseangkutan. Namun demikian, karena pada waktu lalu tidak dikenal bukti kepemilikan hak atas tanah adat, dan pada umumnya yang berkedudukan sebagai wajib pajak tanah adalah pemilik tanah yang bersangkutan, maka hampir selalu wajib pajak adalah pemilik persil tersebut. ${ }^{9}$

Pengaturan mengenai diberikan kesempatan bagi pemilik hak atas tanah yang belum bersertifikat untuk bisa menggunakan tanahnya sebagai jaminan dalam suatu perjanjian antara lain dalam perjanjian kredit untuk memperoleh dana, di samping untuk melindungi golongan ekonomi lemah untuk memperoleh dana, juga untuk mendorong dilakukannya pensertifikatan hak atas tanah yang dijadikan objek Hak Tanggungan.

Dari ketentuan Pasal 10 ayat (3) terlihat bahwa dalam hal hak atas tanah yang dijadikan objek Hak Tanggungan belum bersertipikat, maka dilakukan pendaftaran hak atas tanah tersebut bersamaan dilakukannya pembebanan Hak Tanggungan. Dengan demikian pada saat pendaftaran Hak Tanggungan maka tanah yang bersangkutan sudah bersertipikat. Hal ini berkaitan dengan syarat bagi pemegang Hak tanggungan harus orang atau badan hukum yang berwenang untuk melakukan perbuatan hukum terhadap objek Hak Tanggungan yang ditegaskan dalam Pasal 8 Ayat (1) UUHT. Bukti adanya kewenangan ini harus sudah ada pada saat Hak Tanggungan didaftarkan di kantor pertanahan. Hal demikian dimaksudkan untuk memberikan perlindungan hukum bagi

9. Ibid, hlm. 275. 
kreditor pemegang Hak Tanggungan, karena jika debitor wanprestasi dapat dilakukan eksekusi terhadap objek Hak Tanggungan dan tidak menimbulkan sengketa karena ada kejelasan siapa pihak yang berwenang.

\section{Pembebanan Hak Tanggungan dengan Objek Tanah yang Belum Bersertipikat}

Hak Tanggungan bersifat accessoir, artinya bahwa Hak Tanggungan itu merupakan perjanjian ikutan/pelengkap dari perjanjian pokok, sehingga ada atau tidak adanya Hak Tanggungan ini tergantung dari ada atau tidak adanya perjanjian pokok. Dalam hal Hak Tanggungan ini digunakan untuk menjamin pelaksanaan prestasi dalam perjanjian kredit, maka sebelum adanya Hak Tanggungan pasti didahului dengan adanya perjanjian kredit. Pemberian kredit oleh bank sebagai kreditor kepada debitor mempunyai risiko yang besar, karena ada kemungkinan bahwa debitor melakukan wanprestasi, baik terlambat memenuhi prestasi, memenuhi prestasi tidak sebagaimana yang diperjanjikan maupun tidak memenuhi prestasi sama sekali. Oleh karena itu untuk mengantisipasi adanya kerugian di kemudian hari, pada umumnya bank selalu berhati-hati dalam memberikan kredit. Oleh karena itu sebelum kredit disetujui, maka dilakukan analisis secara seksama terhadap calon debitor. Dalam perjanjian kredit di bank, jaminan utama berupa keyakinan bahwa debitor akan sanggup membayar angsuran. Dalam UU Nomor 7 Tahun 1992 Tentang Perbankan, yang telah diubah dengan UU No. 10 Tahun 1998, pada Pasal 8 disebutkan bahwa "Dalam memberikan kredit, bank umum wajib mempunyai keyakinan atas kemampuan dan kesanggupan debitor untuk melunasi hutangnya sesuai yang diperjanjikan. Untuk memperoleh keyakinan akan kesanggupan debitor, dalam pembiayaan kredit bank ada berbagai pedoman yang digunakan, antara lain adalah Prinsip 5C, yang terdiri dari (1) Character, (2) Capacity, (3) Capital, (4) Condition of economy, (5) Collateral. ${ }^{10}$

Jaminan menjadi faktor yang sangat menentukan dalam pemberian kredit di bank. Salah satu jaminan yang sering digunakan adalah Hak Tanggungan.

Pada umumnya perjanjian kredit ini dibuat dalam bentuk baku, karena dibuat oleh salah satu pihak dalam perjanjian. Dengan demikian pihak yang tidak ikut menentukan perjanjian seringkali merasa ada pada posisi yang lemah. Perjanjian kredit ini biasanya dibuat oleh bank sebagai keditor. Meskipun antara bank satu dengan yang lainnya ada perbedaan, namun pelaksanaannya ada kemiripan.

Dalam praktik, pembebanan jaminan atas tanah yang belum bersertipikat didahului dengan pembuatan Surat Kuasa Membebankan Hak Tanggungan (SKMHT). Oleh Notaris/PPAT rekanan Bank, yang kemudian dilanjutkan dengan pembuatan APHT. Dalam hal ini menurut peneliti kurang tepat karena pembuatan SKMHT sebenarnya bukan untuk kondsi bahwa tanah yang menjadi objek Hak Tanggungan merupakan tanah yang belum bersertipikat, tetapi diadakan dalam hal Pemberi Hak Tanggungan tidak dapat hadir dalam Pemberian Hak Tanggungan. Pada asasnya pemberian Hak Tanggungan wajib dilakukan oleh Pemberi Hak Tanggungan. Hal ini sesuai dengan asas umum yang menyatakan bahwa "pada asasnya tindakan hukum harus dilakukan oleh yang berkepentingan sendiri. Namun demikian ketentuan tersebut dapat disimpangi dan orang atau badan hukum dapat menguasakan tindakannya kepada orang atau pihak lain. ${ }^{11}$

Pengecualian asas tersebut di atas diatur secara jelas dalam Penjelasan Pasal 15 ayat (1) UUHT, yang menyebutkan bahwa "hanya apabila benar-benar diperlukan orang boleh menggunakan Surat Kuasa Membebankan Hak Tanggungan (SKMHT). Jadi SKMHT hanya diperkenankan dalam keadaan khusus, yakni apabila Pemberi Hak Tanggungan tidak dapat hadir sendiri di hadapan PPAT. Dalam hal ini Pemberi Hak Tanggungan wajib menunjuk pihak lain sebagai kuasanya dalam pembuatan SKMHT yang dibuat dengan akta otentik dan pembuatannya diserahkan oleh

10.Munir Fuady, 1995, Hukum tentang Pembiayaan dalam Teori dan Praktek, (Leasing, Factoring, Modal Ventura, Pembiayaan Konsumen, Kartu Kredit), Bandung, PT Citra Aditya Bakti, hlm. 16

11. Boedi Harsono, 2003, Hukum Agraria Indonesia sejarah Pembentukan Undang-undang Pokok Agraria, Isi dan Pelaksanaannya, Jakarta, Djambatan, hlm. 435. 
Notaris atau PPAT. ${ }^{12}$

Jangka waktu SKMHT untuk hak atas tanah yang belum bersertipikat adalah 3 bulan, kemudian harus diikuti dengan pembuatan APHT. Apabila SKMHT tidak diikuti dengan pembuatan APHT maka konsekuensinya SKMHT tersebut batal demi hukum. Hal ini ditegaskan dalam Pasal 15 ayat (5) UUHT. Akan tetapi batas waktu tersebut tidak menutup kemungkinan dibuatnya SKMHT baru.

SKMHT dibuat dalam jangka waktu 3 bulan. Jangka waktu 3 bulan ini dimaksudkan untuk melengkapi surat-surat yang diperlukan untuk pendaftaran hak atas tanah yang tentunya membutuhkan waktu untuk memperolehnya.

Dalam praktik sebelum sertipikat hak atas tanah jadi, maka belum bisa dibuat APHT, meskipun jangka waktu SKMHT habis. Dalam hal demikian dibuatkan SKMHT baru. Setelah sertifikat hak atas tanah terbit, kemudian baru diikuti dengan pembuatan APHT. Hal demikian tidak sesuai dengan yang ditentukan dalam Pasal 10 ayat (3) UUHT menyebutkan bahwa

"Apabila objek Hak Tanggungan berupa hak atas tanah yang berasal dari konversi hak lama yang telah memenuhi syarat untuk didaftarkan akan tetapi pendaftarannya belum dilakukan, pemberian Hak Tanggungan dilakukan bersamaan dengan permohonan pendaftaran hak atas tanah yang bersangkutan."

Dari ketentuan Pasal 10 ayat (3) UUHT tersebut terlihat bahwa untuk pembebanan Hak tanggungan terhadap hak atas tanah yang belum bersertipikat, maka pemberian Hak Tanggungan dilakukan bersamaan dengan permohonan pendaftaran hak atas tanah yang bersangkutan. Dengan demikian seharusnya pada waktu pembuatan APHT oleh PPAT sekaligus dilakukan pendaftaran hak atas tanah, sehingga tidak perlu menunggu keluarnya sertipikat hak atas tanah. Sertifikat hak atas tanah sebagai bukti adanya kewenangan Pemberi Hak Tanggungan untuk melakukan perbuatan hukum terhadap tanah yang menjadi objek Hak Tanggungan diperlukan pada saat pendaftaran Hak
Tanggungan di Kantor Pertanahan.

Ketentuan Pasal 10 ayat (3) tersebut berkaitan dengan ketentuan bahwa Pemberi Hak Tanggungan harus orang yang berwenang untuk melakukan perbuatan hukum terhadap objek Hak Tanggungan. Hal ini ditegaskan dalam Pasal 8 ayat (1) UUHT yang menyebutkan bahwa Pemberi Hak Tanggungan adalah orang perseorangan atau badanhukum yang mempunyai kewenangan untuk melakukan perbuatan hukum terhadap obyekHak Tanggungan yang bersangkutan. Selanjutnya dalam Pasal 8 ayat (2) disebutkan bahwa kewenangan untuk melakukan perbuatan hukum terhadap obyek Hak Tanggungan sebagaimana dimaksud pada ayat (1) harus ada pada pemberi HakTanggungan pada saat pendaftaran Hak Tanggungan dilakukan.

Dalam hal pembuatan APHT harus menunggu selesainya pendaftaran hak atas tanah, maka tujuan diberikannya kesempatan bagi pemilik hak atas tanah yang belum bersertipikat untuk memperoleh kredit menjadi tidak terwujud, karena lebih memperpanjang waktu proses pemberian Hak Tanggungan.

APHT ini dibuat rangkap 4, yang 2 lembar bermeterai, 1 lembar digunakan sebagai arsip di Kantor PPAT dan 1 lembar untuk proses pendaftaran Hak Tanggungan ke kantor pertanahan. 2 lembar lagi tidak bermaterai untuk diberikan kepada kreditor dan debitor. Dalam hal dibuat SKMHT, maka pembuatan APHT dilengkapi dengan salinan SKMHT.

Setelah APHT selesai dibuat, 7 hari kemudian didaftarkan di kantor pertanahan. Setelah berkas-berkas yang diperlukan untuk pendaftaran Hak tanggungan dikirim oleh PPAT ke kantor pertanahan, kemdian Kepala Kantor Pertanahan akan melakukan pemeriksaan terhadap kelengkapan berkasberkas tersebut. Apabila berkas telah lengkap maka epala Kantor Pertanahan akan mengirimkan lembar salah satu surat engantar PPAT yang sudah dibubuhi tanggal penerimaan. Jika ada kekurangan kelengkapan berkas pendaftaran maka Kepala Kantor Pertanahan akan

\footnotetext{
12. Maria S.W. Sumardjono, 2001, Kebijakan Pertanahan antara Regulasi dan Implementasi, Jakarta, Buku Kompas, hlm, 126
} 
memberitahukan pula kekurangannya.

Setelah Kepala Kantor Pertanahan menerima berkas pendaftaran secara lengkap maka Kepala Kantor Pertanahan akan mendaftarkan Hak tanggungan dan mencatatnya pada buku tanah Hak tanggungan dan sertipikat hak atas tanah yang bersangkutan dan memberi tanggal ketujuh setelah peneriman secara lengkap berkas pendaftaran Hak tanggungan, apabila hari ketujuh tersebut jatuh pada hari libur maka diberi tanggal hari berikutnya.

Sebagai bukti adanya Hak Tanggungan maka dikeluarkan sertipikat Hak Tanggungan yang yang mencantumkan irah-irah DEMI K E A D I L A N B ER D A S A R K A N KETUHANAN YANG MAHA ESA. Hal ini berarti bahwa sertipikat Hak Tanggungan mempunyai kekuatan eksekutorial sama dengan putusan pengadilan yang berkekuatan hukum tetap.

Menurut Abdurrahman, ${ }^{13}$ dengan berlakunya UUHT, maka kemungkinan untuk menjadikan tanah-tanah hak adat sebagai agunan hanya tinggal sejarah hukum saja, karena dalam penjelasan Pasal 10 ayat (3) menunjukkan bagaimana caranya untuk meningkat pemberian agunan tersebut menjadi hak tanggungan. UUHT bukan saja bermaksud memperlancar arus perkreditan, yang berarti juga menunjang misi perbankan, tetapi juga lebih menekankan aspek kepastian hukum, yaitu keharusan untuk didaftar dan dengan sendirinya untuk lebih mendorong kegiatan pendaftaran tanah di Indonesia

\section{Simpulan}

Berdasarkan uraian pembahasan di atas, maka dapat disimpulkan sebagai berikut:

1. Pembebanan Hak Tanggungan dengan objek hak atas tanah yang belum bersertipikat sudah diatur daläm UUHT yang dimaksudkan untuk memberikan kesempatan kepada orang yang memiliki hak atas tanah yang seharusnya bisa didaftarkan tetapi belum dilakukan pendaftaran untuk mendapatkan kredit. Di samping itu juga dimaksudkan untuk mendorong pensertifikatan hak atas tanah.
2. Dalam hal objek Hak Tanggungan adalah hak atas tanah yang belum bersertipikat, menurut UUHT seharusnya pada waktu pemberian Hak Tanggungan dengan dibuatnya APHT oleh PPAT juga dilakukan pendaftaran hak atas tanah yang bersangkutan. $\mathrm{Namun}$ demikian di dalam pelaksanaannya ternyata pada umumnya dilakukan pendaftaran hak atas tanah terlebih dahulu dan menunggu sampai keluarnya sertipikat hak atas tanah. Pemberian hak Tanggungan tidak langsung dibuatkan APHT, tetapi terlebih dahulu dibuat SKMHT, padahal dalam ketentuan UUHT, pembuatan SKMHT adalah dalam hal Pemberi Hak Tanggungan tidak dapat hadir dalam pemberian Hak Tanggungan, bukan untuk pemberian hak tanggunga terhadap hak atas tanah yang belum bersertipikat. Dengan demikian maksud diberikannya kesempatan bagi pemilik hak atas tanah yang belum bersertipikat untuk memperoleh kredit sebagaimana ditentukan oleh UUHT menjadi tidak terwujud.

\section{Daftar Pustaka}

Malikhatun Badriyah Siti, 2005, Jaminan Fidusia di Indonesia (setelah Berlakunya Undang-undang No. 42 Tahun 1999), Semarang, Badan Penerbit Universitas Diponegoro.

Fuady Munir, 1995, Hukum tentang Pembiayaan dalam Teori dan Praktek, (Leasing, Factoring, Modal Ventura, Pembiayaan Konsumen, Kartu Kredit), , Bandung, Citra Aditya Bakti.

Fuady Munir, 2013, Hukum Jaminan Utang, Jakarta, Erlangga.

Harsono Boedi , 2003Hukum Agraria Indonesia sejarah Pembentukan Undang-undang Pokok Agraria, Isi dan Pelaksanaannya, Jakarta Djambatan.

13. Abdurrahman dalam Rahmadi Usman, 2009, Hukum Jaminan Keperdataan, Cetakan Kedua, Jakarta, Sinar Grafika, hlm. 407. 
Hartono Sri Redjeki 2007, Hukum Ekonomi Indonesia, Malang, Bayumedia Publishing.

Kashadi, 2000, Hak Tanggungan dan Jaminan Fidusia, , Semarang, Fakultas Hukum Universitas Diponegoro.

Mertokusumo Sudikno, 2012, Teori Hukum (Edisi Revisi), Yogyakarta, Cahaya Atma Pustaka.

Mertokusumo Sudikno, 1996. Penemuan Hukum Sebuah Pengantar, Yogyakarta, Liberty.

Rahman Hasanudin, 1996, Aspek-aspek Hukum Perikatan Kredit Perbankan, , Bandung, PT Citra aditya Bakti

Satrio J., 2002, Hukum Jaminan, Hak Jaminan Kebendaan, Hak Tanggungan, Buku 2, Cetakan Kesatu, Bandung, Citra Aditya Bakti.

S.W. Sumardjono Maria, 2001, Kebijakan Pertanahan antara Regulasi dan Implementasi, , Jakarta, Buku Kompas.

Usman, 2009, Rahmadi Hukum Jaminan Keperdataan, Cetakan Kedua, , Jakarta Sinar Grafika.

Kitab Undang-undang Hukum Perdata.

Undang-Undang Nomor 10 Tahun 1998 Tentang Perubahan Terhadap Undang-undang Nomor 7 Tahun 1992 Tentang Perbankan;

Undang-Undang No. 4 Tahun 1996 Tentang Hak Tanggungan(UUHT);

Undang-Undang Nomor 7 Tahun 1972 Tentang Perbankan;

Undang-Undang Nomor 5 Tahun 1960 tentang Peraturan Dasar PokokpokokAgraria 